\title{
Multicomponent Binders with Off-Grade Fillers
}

\author{
S.-A. Murtazaev ${ }^{1,2,3}$, M. Salamanova ${ }^{1,2(\bowtie)}$, M. Saydumov ${ }^{1}$, \\ A. Alaskhanov ${ }^{1}$, and M. Khubaev ${ }^{1}$ \\ ${ }^{1}$ Millionshchikov Grozny State Oil Technical University, Grozny, Russia \\ Madina_salamanova@mail.ru \\ 2 Ibragimov Complex Research Institute, RAS, Grozny, Russia \\ ${ }^{3}$ Academy of Sciences of the Chechen Republic, Grozny, Russia
}

\begin{abstract}
The paper deals with issues related to development of multicomponent binders (MCB) and high-quality concretes based on them. The production of such binders is based on the use of finely divided mineral additives of natural and technogenic origin. Particular attention is paid to the aggregate, the strength of coarse aggregate should be at least $20 \%$ higher than the strength of concrete, and the maximum particle size should not exceed 8-20 mm. At present, considerable experience was accumulated for production of multicomponent binders, and the results of studies conducted in this direction showed that the raw material potential of the Republic allowed obtaining high-quality class B30-40 concrete, and if we expanded the geography of the use of natural resources by regions of the North Caucasus, we could produce concretes with higher strength.
\end{abstract}

Keywords: High-quality concretes - Composite binders •

Reactive mineral components • Volcanic ash • Thermal power plant (TPP) ash •

Fractionated filler

\section{Introduction}

Concrete is one of the oldest materials, but its potential and possibilities seem inexhaustible (Murtazaev et al. 2016; Nesvetaev et al. 2018; Stelmakh et al. 2018), since at all times of its existence and in the future this material will occupy a leading place among a huge variety of building compositions.

The active component of concrete is cement. It is known that varying finely dispersed mineral additives in its composition results in modern composite materials, which properties will vary in wide ranges (Udodov 2015; Salamanova et al. 2017).

In accordance with GOST 31108-2003, granulated slag, fuel ashes, including acidic or basic fly ash, microsilica, burnt clay, burnt shale, marl, quartz sand, etc. are used as mineral components - main components of cement (Udodov 2015; Murtazaev et al. 2016). Various mineral additives can be used as auxiliary components of cement, which will not significantly increase the water demand of cement and reduce durability of concrete. 


\section{Methods and Materials}

As part of the work carried out in this direction, we developed formulations of multicomponent binders, which include mineral additives of natural and technogenic origin.

The North Caucasus has large reserves of natural raw materials for these developments, the chemical analysis of the mineral components used in the studies is shown in Table 1.

Table 1. The chemical composition of mineral components, wt.\%

\begin{tabular}{l|l|r|r|r|r|r|l|l|l}
\hline Type & $\mathrm{MgO}$ & $\mathrm{Al}_{2} \mathrm{O}_{3}$ & $\mathrm{SiO}_{2}$ & $\mathrm{~K}_{2} \mathrm{O}$ & $\mathrm{CaO}$ & $\mathrm{Fe}_{2} \mathrm{O}_{3}$ & $\mathrm{TiO}_{2}$ & $\mathrm{SO}_{3}$ & $\mathrm{LOI}$ \\
\hline TPP ash & 2,49 & 23,89 & 42,88 & 0,48 & 4,6 & 7,95 & 0,11 & 0,66 & 16,9 \\
\hline Volcanic ash & 0,20 & 13,57 & 73,67 & 6,00 & 1,79 & 1,52 & 2,85 & - & 0,40 \\
\hline Limestone flour & 0,72 & 1,55 & 5,05 & 0,6 & 90,14 & 1,4 & - & 0,49 & - \\
\hline Quartz powder & 6,32 & 14,99 & 73,83 & 1,83 & 0,6 & 0,97 & 1,32 & 0,14 & - \\
\hline
\end{tabular}

\section{Results and Discussion}

To produce multicomponent binders, the additives under study were ground in VM-20 laboratory ball vibratory mill for 30 and $40 \mathrm{~min}$. Figure 1 shows dependence of specific surface of mineral additives on the grinding time.

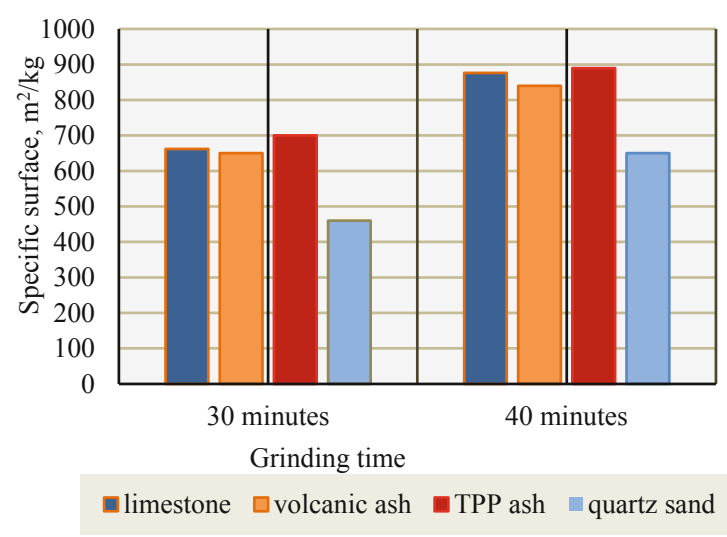

Fig. 1. Specific surface of mineral components

To determine the optimal degree of saturation of Portland cement (PC) - mineral powder (MP) system (PC:MP), samples were prepared from the proposed multicomponent binder formulations and properties (Table 2). 
Table 2. Properties of multicomponent binders (MCB)

\begin{tabular}{|c|c|c|c|c|c|c|}
\hline \multirow[t]{2}{*}{ No. } & \multirow{2}{*}{$\begin{array}{l}\text { Mineral } \\
\text { Powder }\end{array}$} & \multirow[t]{2}{*}{$P C: M P$} & \multirow{2}{*}{$\begin{array}{l}\text { Normal den- } \\
\text { sity, } \%\end{array}$} & \multicolumn{2}{|c|}{$\begin{array}{l}\text { Setting time, } \\
\text { hour-min }\end{array}$} & \multirow{2}{*}{$\begin{array}{c}\text { Activity, } \\
\text { MPa }\end{array}$} \\
\hline & & & & start & end & \\
\hline 1 & \multirow{2}{*}{ Limestone flour } & $70 / 30$ & 25,5 & $2-05$ & $3-00$ & 35,8 \\
\hline 2 & & $60 / 40$ & 26,8 & $2-15$ & $3-20$ & 30,4 \\
\hline 3 & \multirow{2}{*}{ Quartz powder } & $70 / 30$ & 24,6 & $1-30$ & $2-10$ & 41,8 \\
\hline 4 & & $60 / 40$ & 27,0 & $1-55$ & $2-50$ & 39,7 \\
\hline 5 & \multirow[t]{2}{*}{ TPP Ash } & $70 / 30$ & 26,4 & $2-10$ & $3-15$ & 34,1 \\
\hline 6 & & $60 / 40$ & 28,1 & $2-25$ & $3-35$ & 28,2 \\
\hline 7 & \multirow[t]{2}{*}{ Volcanic ash } & $70 / 30$ & 25,2 & $1-35$ & $2-15$ & 42,6 \\
\hline 8 & & $60 / 40$ & 26,5 & $2-05$ & $3-00$ & 40,3 \\
\hline 9 & - & 100 & 25,0 & $2-20$ & $3-40$ & 48,0 \\
\hline
\end{tabular}

The results of the studies showed that the most rational are the compositions of binders using mineral powders of volcanic ash and quartz powder with a ratio of $70: 30 \%$, with a specific surface of $876 \mathrm{~m}^{2} / \mathrm{kg}$ and $650 \mathrm{~m}^{2} / \mathrm{kg}$, respectively, with a typical increase in the activity of the binder and a slight increase in normal thickness, and $30 \%$ of portland cement are saved.

Next, a concrete mixture with P2 mobility mark was produced, the samples were subjected to heat and humidity treatment (HHT) in a steam chamber at $2+3+7+2 \mathrm{~h}$ at an isothermal holding temperature of $80^{\circ} \mathrm{C}$. Table 3 shows the experimental compositions and properties of the studied concretes.

Table 3. The compositions of the studied concretes

\begin{tabular}{|c|c|c|c|c|c|c|c|c|}
\hline \multirow[t]{2}{*}{$\begin{array}{l}\text { No } \\
\text { composition }\end{array}$} & \multirow[t]{2}{*}{$\begin{array}{l}\text { Mineral } \\
\text { powder }\end{array}$} & \multicolumn{4}{|c|}{$\begin{array}{l}\text { Consumption of } \\
\text { materials, } \mathrm{kg} / \mathrm{m}^{3}\end{array}$} & \multirow[t]{2}{*}{$\begin{array}{l}\text { Average density, } \\
\mathrm{kg} / \mathrm{m}^{3}\end{array}$} & \multicolumn{2}{|c|}{$\begin{array}{l}\text { Compressive } \\
\text { strength, } \mathrm{MPa}\end{array}$} \\
\hline & & $\begin{array}{l}\text { MCB- } \\
70\end{array}$ & ACS & DS & B & & $\begin{array}{l}\text { After } \\
\text { HHT }\end{array}$ & $\begin{array}{l}\text { Age } 28 \\
\text { days }\end{array}$ \\
\hline 1 & $\begin{array}{l}\text { Limestone } \\
\text { flour }\end{array}$ & 450 & 1100 & 680 & 220 & 2430 & 43,3 & 38,4 \\
\hline 2 & $\begin{array}{l}\text { Quartz } \\
\text { powder }\end{array}$ & 450 & 1100 & 680 & 210 & 2410 & 50,2 & 45,9 \\
\hline 3 & $\begin{array}{l}\text { Volcanic } \\
\text { ash }\end{array}$ & 450 & 1100 & 680 & 215 & 2415 & 52,1 & 46,5 \\
\hline 4 & TPP ash & 450 & 1100 & 680 & 230 & 2420 & 37,7 & 35,9 \\
\hline 5 & $\mathrm{PC}$ & 450 & 1100 & 680 & 200 & 2420 & 51,5 & 48,6 \\
\hline
\end{tabular}

Note: PC - Portland cement; ACS - Alagir crushed stone fraction 5-20 mm; FS - fractionated fine filled based on the sands of the Alagir and Chervlensk deposits.

We established that the strength of concrete after HHT is $12 \%$ higher than the indicators of the strength of concrete after 28 days of natural hardening. The use of MCB-70 with volcanic ash showed the best results on the compressive strength of 
concrete in comparison with other additives and slightly inferior to similar indicators of control samples (Murtazaev et al. 2016; Stelmakh et al. 2018). The study of operational characteristics (Table 4) showed that the indicators of these properties depend on the composition of the MCB-70 and its activity, as well as on the type and value of the porosity of the material.

Table 4. Operational properties of concrete using MCB-70

\begin{tabular}{l|l|l|l|l}
\hline \multirow{2}{*}{ Indicators } & \multicolumn{3}{l}{} \\
\cline { 2 - 5 } & $\begin{array}{l}\text { Mineral powder } \\
\text { flour }\end{array}$ & $\begin{array}{l}\text { Volcanic } \\
\text { ash }\end{array}$ & $\begin{array}{l}\text { TPP } \\
\text { ash }\end{array}$ & $\begin{array}{l}\text { Quartz } \\
\text { powder }\end{array}$ \\
\hline MCB-70 activity, MPa & 35,8 & 42,6 & 34,1 & 41,8 \\
\hline Compressive strength, MPa & 38,4 & 46,5 & 35,9 & 45,9 \\
\hline Flexural strength, MPa & 4,1 & 4,9 & 3,8 & 4,4 \\
\hline Porosity, \% & 9,7 & 7,6 & 12,4 & 6,9 \\
\hline Frost resistance, cycle & F300 & F350 & F200 & F350 \\
\hline Pressure, MPa & 1,4 & 1,8 & 1,2 & 1,8 \\
\hline Water absorption, \% & 4,2 & 3,5 & 5,2 & 3,6 \\
\hline $\begin{array}{l}\text { Water resistance, } \mathrm{Kr}-\text { softening } \\
\text { coefficient }\end{array}$ & 0,79 & 0,89 & 0,63 & 0,90 \\
\hline
\end{tabular}

\section{Conclusions}

Multicomponent binders based on mineral powders of natural and man-made origin allow to obtain high-quality concrete of class of strength B30-40, including for high monolithic construction.

\section{References}

Udodov SA (2015) Re-introduction of plasticizer as a tool for controlling the mobility of concrete mix. In: Proceedings of the Kuban State Technological University, no 9, pp 175-185

Murtazaev S-Y, Salamanova MS, Bisultanov RG, Murtazaeva TS-A (2016) High-quality modified concretes using a binder based on a reactive active mineral component. Stroitelnyematerialy, no 8, pp 74-80

Nesvetaev G, Koryanova Y, Zhilnikova T (2018) On effect of superplasticizers and mineral additives on shrinkage of hardened cement paste and concrete. In: MATEC Web of Conferences 27, Cep, 27th R-S-P Seminar, Theoretical Foundation of Civil Engineering (27RSP), TFoCE 2018, p 04018

Stelmakh SA, Nazhuev MP, Shcherban EM, Yanovskaya AV, Cherpakov AV (2018) Selection of the composition for centrifuged concrete, types of centrifuges and compaction modes of concrete mixtures. In: Kim Y-H, Parinov IA, Chang S-H (ed) Physics and Mechanics of New Materials and Their Applications (PHENMA 2018) Abstracts \& Schedule, p 337

Salamanova M, Khubaev M, Saidumov M, Murtazaeva T (2017) Self-consolidating concretes with materials of the Chechen Republic and neighboring regions. Int J Environ Sci Educ 11 (18):12719-12724 
Open Access This chapter is licensed under the terms of the Creative Commons Attribution 4.0 International License (http://creativecommons.org/licenses/by/4.0/), which permits use, sharing, adaptation, distribution and reproduction in any medium or format, as long as you give appropriate credit to the original author(s) and the source, provide a link to the Creative Commons license and indicate if changes were made.

The images or other third party material in this chapter are included in the chapter's Creative Commons license, unless indicated otherwise in a credit line to the material. If material is not included in the chapter's Creative Commons license and your intended use is not permitted by statutory regulation or exceeds the permitted use, you will need to obtain permission directly from the copyright holder.

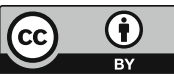

